\title{
Wybrane aspekty projektowania przestrzeni publicznych z uwzględnieniem potrzeb seniorów
}

\author{
Natalia Przesmycka \\ e-mail:n.przesmycka@pollub.pl \\ Michał Dmitruk \\ e-mail:m.dmitruk@pollub.pl \\ Wydziat Budownictwa i Architektury, Katedra Architektury, \\ Urbanistyki i Planowania Przestrzennego, Politechnika Lubelska
}

\begin{abstract}
Streszczenie: Starzenie się społeczeństwa staje się globalnym trendem obserwowalnym w krajach rozwiniętych. Jak wynika z raportu Światowej Organizacji Zdrowia (WHO), wraz z rozwojem miast Europy i Ameryki Północnej zwiększa się odsetek osób po 60 roku życia. Zjawisko to w Polsce obserwowalne jest głównie w przestrzeni osiedli wielorodzinnych z lat 60.-90. XX wieku, gdzie w znacznej mierze nadal mieszkają ich pierwsi mieszkańcy. Osoby starsze w większości przypadków pozostają aktywne fizycznie, społecznie a także pozostają chętne do partycypacji w rozwoju i poprawie warunków bytowych w swoim miejscu zamieszkania. Rozwiązania architektoniczno-urbanistyczne wielokrotnie stanowią istotne bariery utrudniające pełny udział osób starszych w życiu osiedla. Są to problemy rozwiązywalne, jednakże wymagające znacznych środków finansowych, dogłębnych analiz jak i umiejętnego zaangażowania w procesy modernizacyjne samych zainteresowanych - seniorów. Jak postuluje m.in. wybitny duński architekt Jan Gehl, przyjazne miasto musi zaadaptować istniejącą infrastrukturę jak i świadczone w przestrzeni osiedlowej usługi na potrzeby osób starszych, z jednoczesnym ich czynnym udziałem, a także oferować nowe możliwości, przeciwdziałające ich społecznemu wykluczeniu. Jest to działanie konieczne w celu utrzymania zrównoważonego rozwoju miast.
\end{abstract}

Słowa kluczowe: starzenie się społeczeństwa, partycypacja i integracja społeczna, architektura, urbanistyka, projektowanie uniwersalne.

\section{Wprowadzenie}

Zjawisko wyraźnej urbanizacji kraju jak i fakt iż zgodnie z danymi GUS ${ }^{1}$ ponad 59\% mieszkańców Polski mieszka obecnie w miastach, powoduje iż istotnym problemem wartym poruszenia jest to jak będą wyglądać i funkcjonować miasta w najbliższej przyszłości i komu mają służyć. Ośrodki miejskie są niezwykle ważne dla rozwoju gospodarczego, oferujące wiele możliwości pracy i rozwoju osobistego, zwłaszcza dla ludzi młodych. Nie można jednak oceniać miast jedynie przez pryzmat ekonomicznej wartości. Jest to również przestrzeń życiowa, służąca wypoczynkowi, tworzeniu poczucia bezpieczeństwa i budowaniu relacji społecznych. W tym kontekście starsi mieszkańcy miasta i ich potrzeby zdają się niejednokrotnie być odsuwani na drugi plan, często za sprawą nieprzystosowanej infrastruktury miejskiej, architektury czy rozwiązań urbanistycznych. Selwyn Goldsmith określa to zjawisko mianem niepetnosprawności architektonicznej2 rozumianej jako stan wymuszonej niepełnosprawności lub ograniczenia aktywności fizycznej i społecznej, związanej z występowaniem barier architektonicznych. 
Problem ten dotyczy głównie osób starszych, niepełnosprawnych i rodziców z wózkami dziecięcymi. Zdawać by się mogło, iż przestrzenie osiedli mieszkaniowych są miejscem idealnym do życia dla osób starszych, gdyż zapewniają bliskość funkcji takich jak szpital, kościół czy placówki usługowo-handlowe. Praktyka pokazuje iż ze względu na trudności wynikające z powstawania przeszkód architektonicznych ludzie starsi decydują się na zmianę miejsca zamieszkania na bardziej przyjazne, lub skazani są na izolację wewnątrz najbliższego sąsiedztwa. Do wspomnianych czynników należą m.in.: liczne różnice poziomów ze stromymi schodami, chodniki w złym stanie, brak odpowiedniej komunikacji miejskiej czy dobrze oznaczonych i oświetlonych przystanków, brak miejsc do siedzenia lub wypoczynku, brak publicznych toalet czy ostatecznie brak dźwigów osobowych w budynkach.

Aby miasta rozwijały się w sposób prawidłowy i zgodny zasadami zrównoważonego rozwoju, należy przyjąć jako nadrzędną zasadę iż seniorzy są niezbędną grupą wiekową tworzącą pełnowartościową i kompletną strukturę społeczną miast i mającą realny wpływ na ich funkcjonowanie. Aby utrzymać zadowolenie i komfort życia osób starszych w przestrzeni miejskiej należy zdiagnozować podstawowe problemy związane z architekturą, infrastrukturą i urbanistyką, a następnie przyjąć odpowiednie rozwiązania naprawcze w celu umożliwienia wspomnianym osobom pełnego korzystania z usług, udogodnień i zasobów miejskich.

\section{Akcje na rzecz aktywnego starzenia się}

Jak wynika z badań prowadzonych przez M.P. Lawtona ${ }^{3}$, ograniczenie życiowych perspektyw wynikające z istnienia barier architektonicznych może w znacznym stopniu negatywnie wpływać na komfort psychiczny i kondycję fizyczną osób starszych, przyspieszając procesy starzenia. Likwidując wspomniane bariery, stawiamy pierwszy krok w celu zachęcenia seniorów do aktywnego starzenia się i czynnego udziału w życiu społecznym, bez wywierania presji psychologicznej. Osoby starsze częstokroć podchodzą dwojako do nieuchronności procesów starzenia się: jedni pragną odnaleźć spokój i ukojenie w przestrzeni zamieszkania, po wielu latach pracy, inni natomiast wolą przeciwstawiać się wspomnianym procesom i żyć możliwie jak najaktywniej. Nie należy jednak przewartościowywać jednego sposobu spędzania czasu nad drugi, a umożliwić wszystkim zainteresowanym grupom aktywność i wygodę na oczekiwanym poziomie. Miasto powinno oferować odpowiednie warunki zarówno do biernego wypoczynku, w przyjaznym, bezpiecznym i estetycznie dostosowanym środowisku zamieszkania, jak i również umożliwić większą aktywność ruchową i intelektualną osobom zainteresowanym. Przed wskazaniem rozwiązań architektonicznie właściwych w osiągnięciu powyższych celów, należy zdiagnozować najważniejsze problemy osiedli mieszkalnych, pod kątem jakości użytkowej. Podstawowym problemem dla osób starszych zdaje się być komunikacja i transport. Wielu z nich ostatecznie decyduje sie na niekorzystanie z własnego auta a polega bardziej na komunikacji miejskiej. W przypadku niezapewnienia odpowiednich połączeń, gęsto rozmieszczonych i dobrze oświetlonych przystanków z miejscami siedzącymi, dojść i chodników w należytym standardzie, czy likwidacji barier takich jak liczne schody, izolacja seniorów w przestrzeni miejskiej będzie postępować. Ponadto osoby starsze są w większym stopniu narażone na wypadki komunikacyjne, szczególnie w przypadku niewystarczającej ilości przejść dla pieszych lub ich nieodpowiedniego oznakowania i oświetlenia. Problem w większych miastach stanowią również węzły przesiadkowe, które poprzez złe i nieintuicyjne oznakowanie stanowią problem logistyczny i uniemożliwiają przemieszczanie się na większe dystanse (vide: węzeł przesiadkowy Metro Świętokrzyska, Warszawa). Istotnym problemem i elementem dyskryminującym osoby starsze jest kwestia dostępności (lub jej braku) do obiektów użyteczności publicznej. Wiele budynków, szczególnie tych starszych, pozbawionych jest dźwigów osobowych, posiada podwyższony poziom 0, wymagający wejścia po schodach, jednocześnie nie posiadając ramp wejściowych, posiada ciężkie drzwi wymagające znacznej siły do otworzenia, jak i śliskie posadzki wewnętrzne, zwiększające ryzyko upadku. Często nie posiadają one również ogólnodostępnych toalet, tym bardziej tych dostosowanych do potrzeb osób niepełnosprawnych. Ten sam problem dotyczy wielokrotnie budynków mieszkalnych i usługowych w najbliższym sąsiedztwie. Osoby, które w młodości za czasów PRL z przydziału4 otrzymały mieszkania na czwartym piętrze i mieszkają w nich do dziś, mają obecnie znaczne problemy z poruszaniem się po schodach (brak jest wind) i niejednokrotnie decydują

3 Lawton, M.P., Social ecology and the health of older people, American Journal of Public Health, Vol. 64., No. 3. 1994

4 Zgodnie z założeniami gospodarki mieszkaniowej w PRL - Dekret "o publicznej gospodarce lokalami i kontroli najmu” (Dz. U. $1946 \mathrm{r}$. Nr 4 poz. 27) 
się pozostać w domu. Współczesne przepisy budowlane zarówno w Polsce ${ }^{5}$ jak i za granicą ${ }^{6}$ stawiają wymogi projektowanym budynkom we wspomnianym zakresie a także nakazują dostosowanie budynków istniejących zgodnie z możliwościami technicznymi. Problemem może być również brak zaplanowanych w przestrzeni publicznej funkcji, bądź elementów małej architektury, sprzyjających aktywności intelektualnej - jak kluby seniora, domy kultury, lub fizycznej - siłownie na otwartym powietrzu, aleje i parki spacerowe, wraz z niezbędnymi elementami wyposażenia.
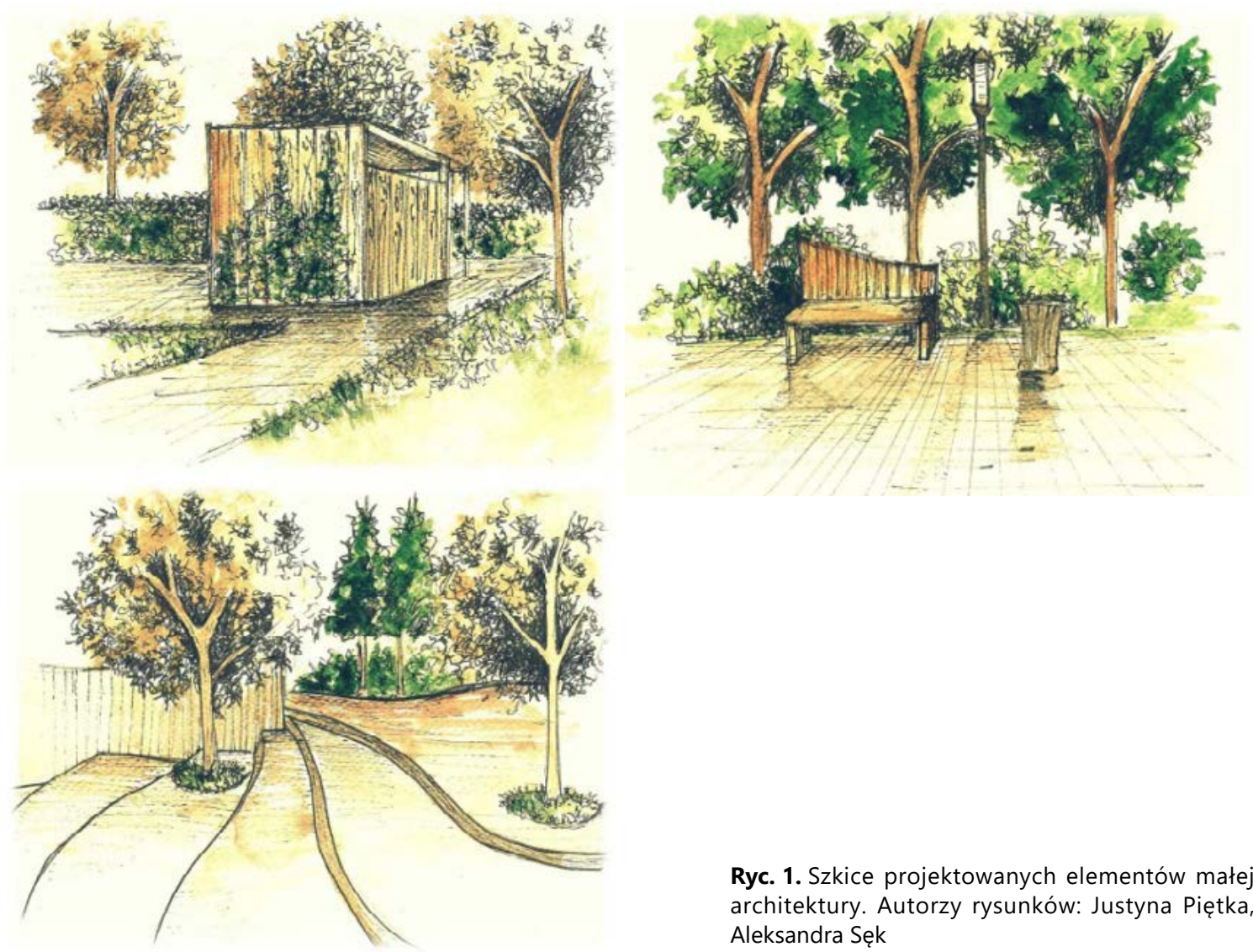

Ryc. 1. Szkice projektowanych elementów małej architektury. Autorzy rysunków: Justyna Piętka, Aleksandra Sęk

Czym więc powinno charakteryzować się miasto sprzyjające aktywnemu starzeniu się? Przede wszystkim powinno być dobrze i świadomie zarządzane przez władze które rozumieją iż miasto dla osób starszych służy tak naprawdę wszystkim mieszkańcom, przy okazji czuwając aby nie dopuścić do tworzenia się w miastach enklaw izolacji i wykluczenia społecznego. Władze miejskie muszą być świadome populacja których z osiedli starzeje się i z jakimi problemami borykają się mieszkańcy. Władze powinny umożliwić pełną partycypację osób starszych w budowaniu przyjaznego miasta. Nie da się zbudować miasta dla seniorów, bez udziału seniorów. Ważne jest aby dane osoby mogły zdefiniować swoje potrzeby i oczekiwania i aby ich głos został wysłuchany. Jako przykład wspomnianego działania można przytoczyć inicjatywę Grupy Sąsiedzkiej RDM, zawiązanej w Lublinie. Wspomniana grupa, zawiązana przez seniorów, zamieszkałych przy ul. Sowińskiego 4 w Lublinie, świadoma problemów architektonicznych ich przestrzeni międzyblokowej wyszła z oddolną inicjatywą na rzecz zmiany sytuacji i zlikwidowania barier architektonicznych. Na początku roku 2013 zwrócono się z prośbą do ówczesnych władz Wydziału Budownictwa i Architektury o przygotowanie koncepcji rewitalizacji przestrzeni międzyblokowej, jednocześnie określając konkretne problemy i cele, m.in.: likwidację progów i schodów,

5 M.in. art. 5 ust. 1 pkt 4 ustawy Prawo budowlane, Rozporządzenie Ministra Infrastruktury z dnia 12 kwietnia 2002 r. w sprawie warunków technicznych, jakim powinny odpowiadać budynki i ich usytuowanie (Dz. U. z 2002 r. Nr 75, poz. 690 z późn. zm.)

6 Np.: Disability Discrimination Act w Wielkiej Brytanii. 
uporządkowanie sposobu parkowania aut w przestrzeni, zapewnienie odpowiedniej liczby siedzisk i elementów małej architektury, służących różnym grupom wiekowym mieszkańców. Koncepcje zostały opracowane przez studentów 2 roku Architektury, pod okiem mgra inż. arch. Michała Dmitruka i zaprezentowane mieszkańcom i władzom miasta. Entuzjazm i energia w działaniu seniorów została dostrzeżona i doceniona, gdyż przeznaczono w Budżecie Miasta Lublina środki na rewitalizację przestrzeni, a prace budowlane zostały zakończone w 2016 roku. Rozwiązania projektowe, szeroko konsultowane z mieszkańcami zdają się podobać i dobrze im służyć.

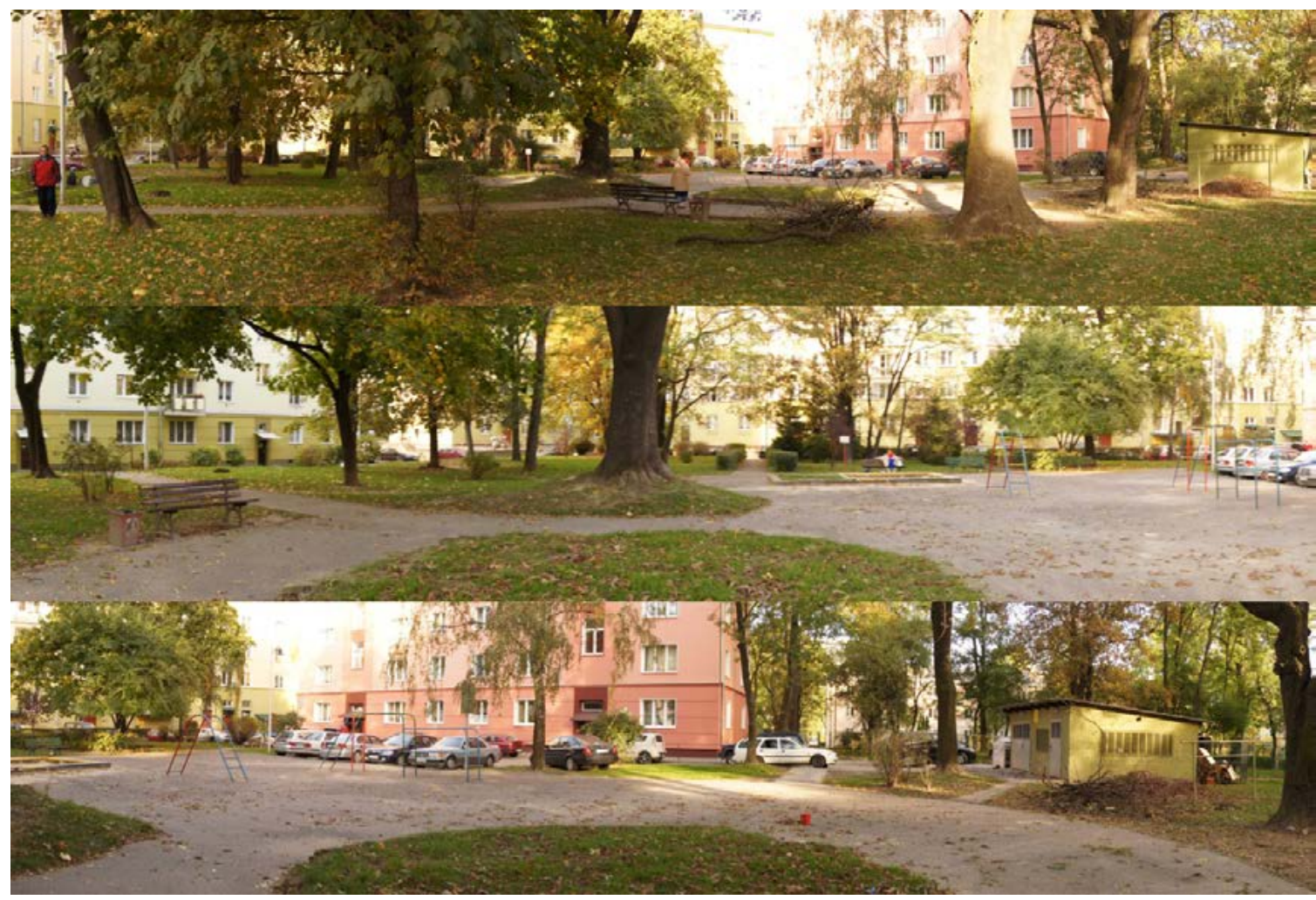

Ryc. 2. Widoki panoramiczne na skwer. Fot. N. Przesmycka 2014

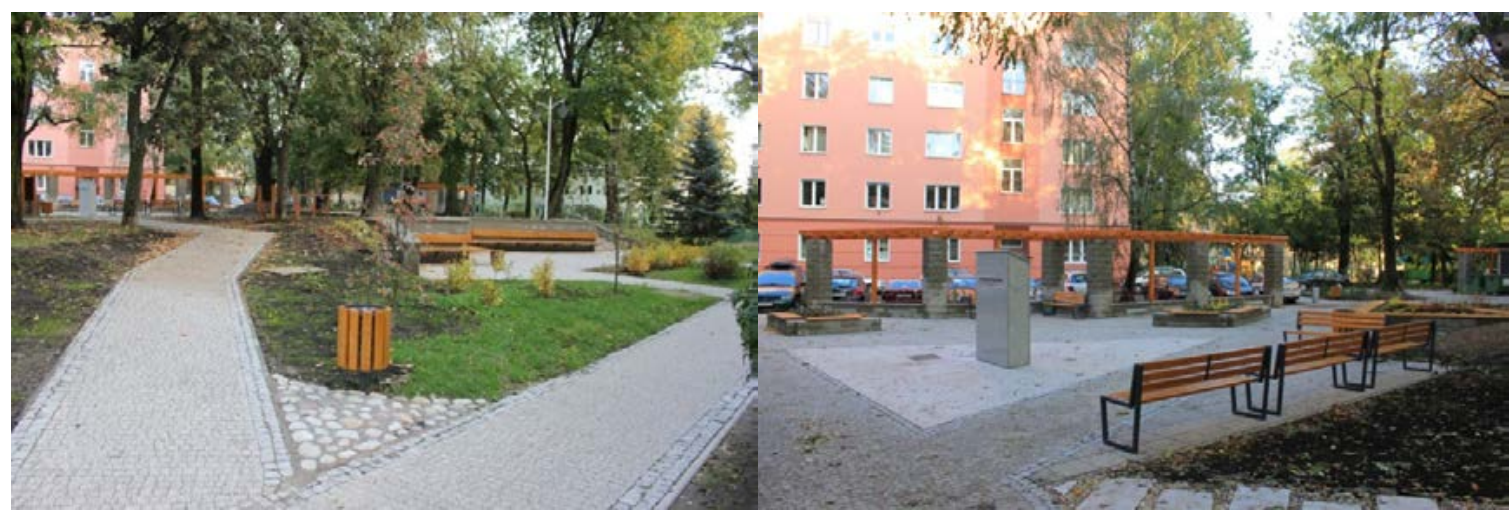

Ryc. 3. Skwer przy ul. Sowińskiego 4 - stan obecny. Fot. M. Dmitruk 2016

Ważna jest również wspomniana wcześniej dostępność do publicznych środków transportu, jak i do samych budynków zamieszkania i innych z którymi użytkownik wchodzi w interakcję. Należy pamiętać o projektowaniu równych bezuskokowych nawierzchni, redukować schody i gdzie możliwe zastępować je pochylniami i rampami, dbać o wyraźne wizualne oznaczenia przejść i przeszkód a w budynkach stosować poręcze, pochwyty 
i antypoślizgowe podłogi. Za przykład usprawnienia komunikacji wewnątrz budynku mogą posłużyć rozwiązania stosowane na osiedlu Ascostaden w Vesteras ${ }^{7}$ (Szwecja), gdzie do budynków czterokondygnacyjnych dostawiono zewnętrzne klatki schodowe, a istniejące zastąpiono dźwigami osobowymi. Zainstalowano też liczne pochylnie, zlikwidowano schody, przez co ułatwiono znacznie poruszanie się osobom starszym w okolicach budynku. Przedmiotem wielu rozważań projektantów, administracji osiedlowych i samych mieszkańców była możliwość finansowania dobudowy wind zewnętrznych poprzez nadbudowę czterokondygnacyjnych budynków. Na Wydziale Budownictwa i Architektury Politechniki Lubelskiej w ramach zajęć z przedmiotu "Collective Housing Design" przeprowadzono studium projektowe mające na celu rozwiązanie problemów komunikacyjnych budynków wykonanych w latach 70-tych XX wieku w technologii OWT-67. Rozwiązania projektowe dotyczyły zarówno komunikacji wewnątrz budynku, jak i rozwiązywały problem poruszania się w przestrzeni okołobudynkowej. Administracje osiedlowe w Polsce coraz częściej dostrzegają wspomniany problem i podejmują odpowiednie kroki zaradcze. Osiedle im. Hetmana Jana Zamoyskiego w Zamościu zaprojektowane zostało w sposób wymuszający częste korzystanie z licznych schodów w przestrzeni międzyblokowej. Po dokonaniu niecierpiących zwłoki termomodernizacji i napraw bieżących, administracja jako priorytet postawiła sobie likwidację schodów i stosowanie pochylni w celu pokonania nierówności terenowych. Pierwsze prace rozpoczęto w 2016 roku.
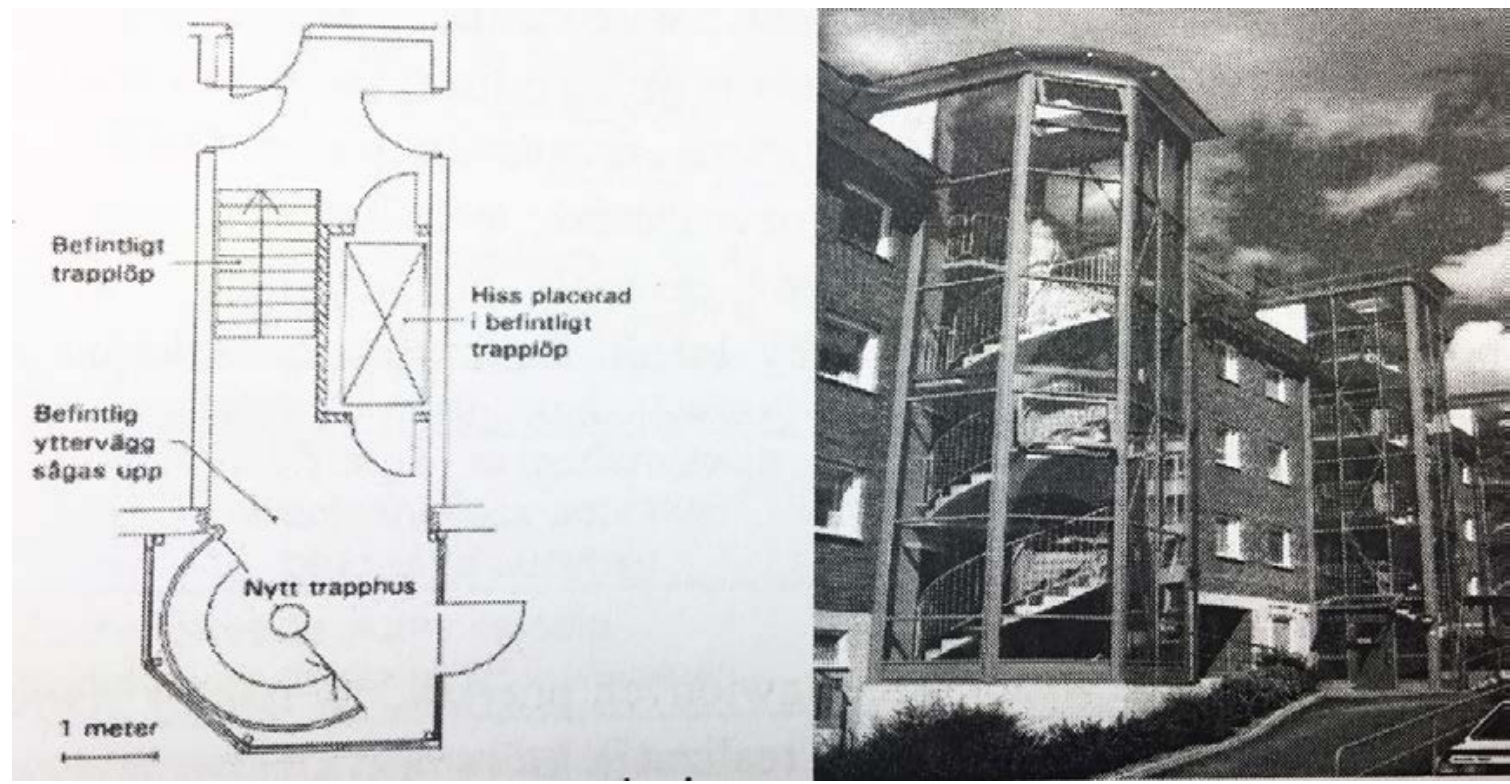

Ryc. 4. Modernizacje na osiedlu Ascostaden w Vesteras (Szwecja). Źródło: A. Ostańska
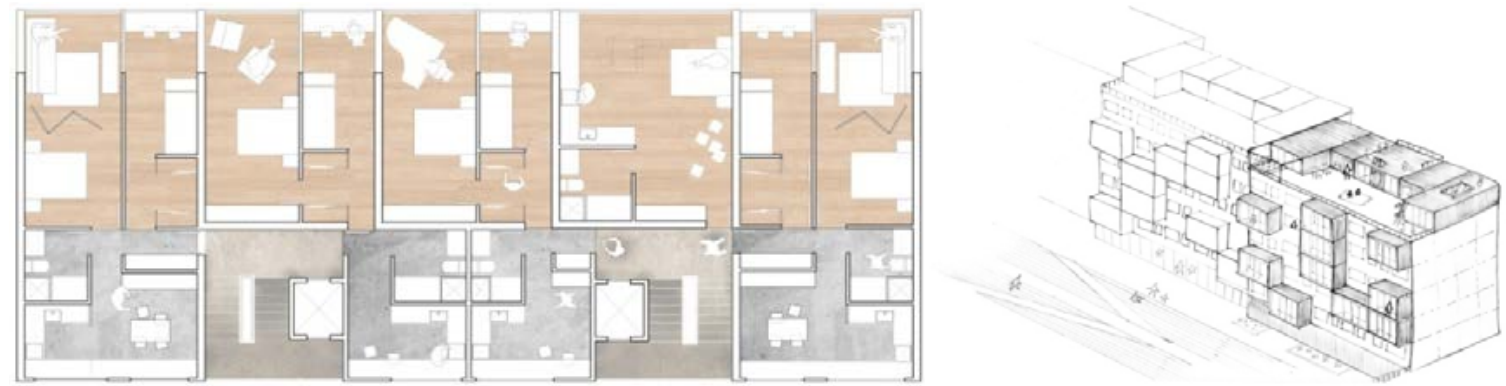

Ryc. 5. Plan budynku w technologii OWT-67 z wprowadzeniem nadbudowy i dźwigów osobowych. Praca studencka. 

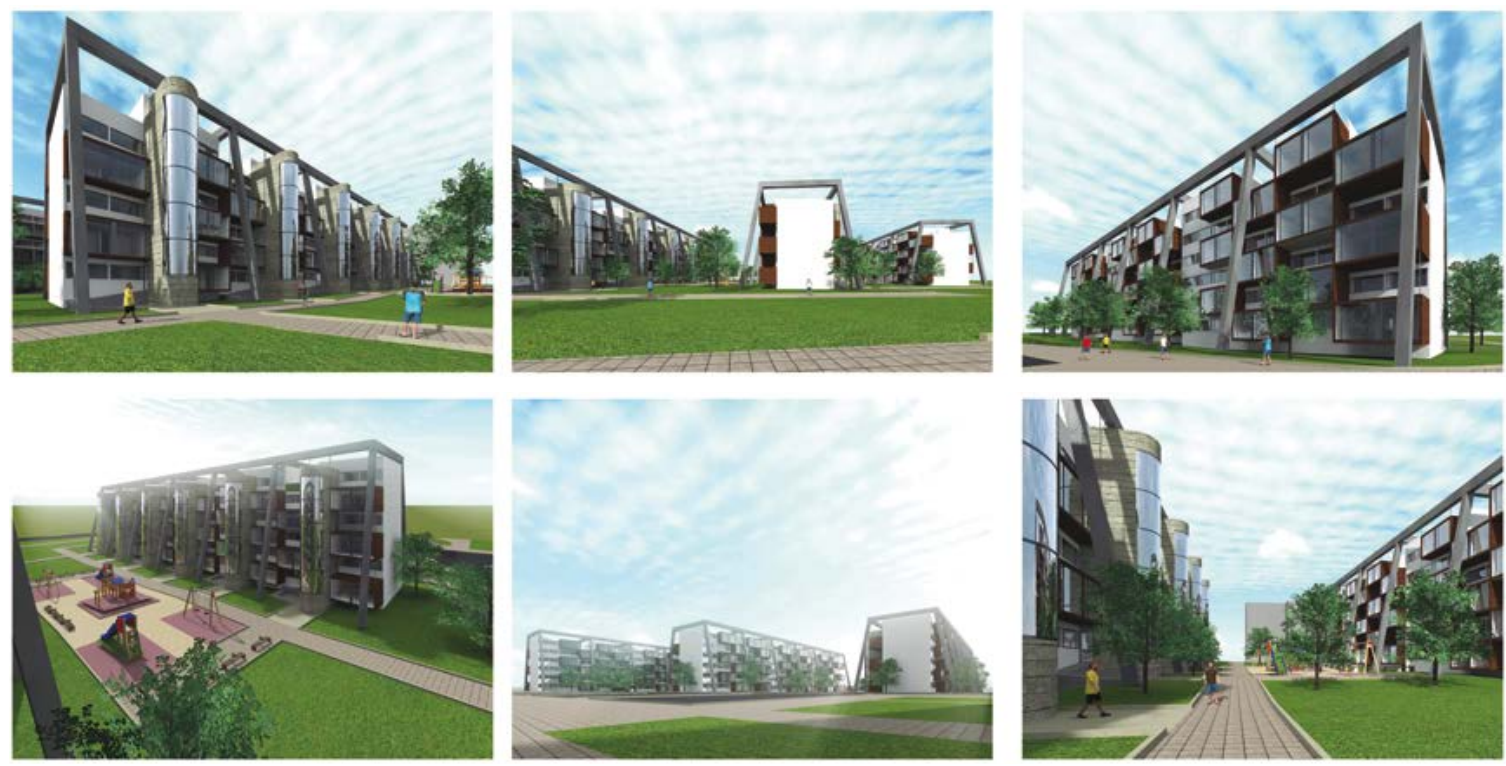

Ryc. 6. Widok budynku w technologii OWT-67 z wprowadzeniem zewnętrznych dźwigów osobowych. Praca studencka.

Istotnym elementem w przestrzeni publicznej jest projektowanie licznych ścieżek i szlaków komunikacyjnych i spacerowych, odseparowanych od traktów komunikacji kołowej, bezpiecznych, oświetlonych, zadbanych i zaopatrzonych w liczne miejskie oazy ${ }^{8}$, czyli atrakcyjne architektonicznie i przyrodniczo miejsca, gdzie można się zatrzymać i odpocząć. Dodatkowo powinny zaopatrzone być w siedziska, zieleń, toalety, opcjonalnie instalacje wodne, oddające nastrój i klimat miejsca.

Miejskie przestrzenie publiczne powinny być żywotne i intensywnie użytkowane. Aby to osiągnąć należy zachęcić ludzi do spędzania czasu w danej przestrzeni. Możliwe jest to np. poprzez wprowadzenie funkcji komercyjnych do parterów okolicznych budynków mieszkalnych, zapewniając zróżnicowanie sposobu użytkowania i sprowokowanie dodatkowej aktywności. Zaprojektowanie otoczenia w sposób elastyczny, zamiast stałego i zorganizowanego pozwoli użytkownikom samodzielnie aranżować sobie przestrzeń, zgodnie z potrzebą chwili, a także ułatwi organizację wydarzeń czasowych, jak spotkania, festiwale czy koncerty. Praktyka projektowa często pokazuje iż przestrzeń publiczna lepiej funkcjonuje, im mniej trwałych i mocno zdefiniowanych elementów się w niej znajduje. Za przykład może posłużyć plac przez budynkiem Centrum Spotkań Kultur w Lublinie, gdzie zaprojektowano jedynie duży skośny element i kilka betonowych siedzisk, a mimo to organizowane są tam liczne atrakcje i jest on chętnie uczęszczany. Niezwykle istotną cechą dobrze obieranej przestrzeni miejskiej jest bezpieczeństwo. Seniorzy znacznie chętniej korzystają z udogodnień oferowanych przez strefie zamieszkania, jeśli czują że ich życiu, zdrowiu i funduszom nie zagraża niebezpieczeństwo. Dotyczy to zarówno ryzyka wystąpienia nieszczęśliwego wypadku, jak i rozbojów lub kradzieży. Poczucie bezpieczeństwa można zwiększyć, stosując liczne punkty świetlne, kamery monitoringu, lub zwiększając częstotliwość patroli policyjnych. Komfort i prestiż jest również istotnym czynnikiem wpływającym na zadowolenie z miejsca zamieszkania nie tylko seniorów, ale i pozostałych mieszkańców. Gustowne i wysokiej jakości wykończenie przestrzeni zamieszkania (w tym i samych budynków), zachowana czystość, jak i brak w przestrzeni osiedlowej aut są istotnymi czynnikami wpływającymi na poczucie komfortu, a co za tym idzie zachęcającymi do podejmowania aktywności. 


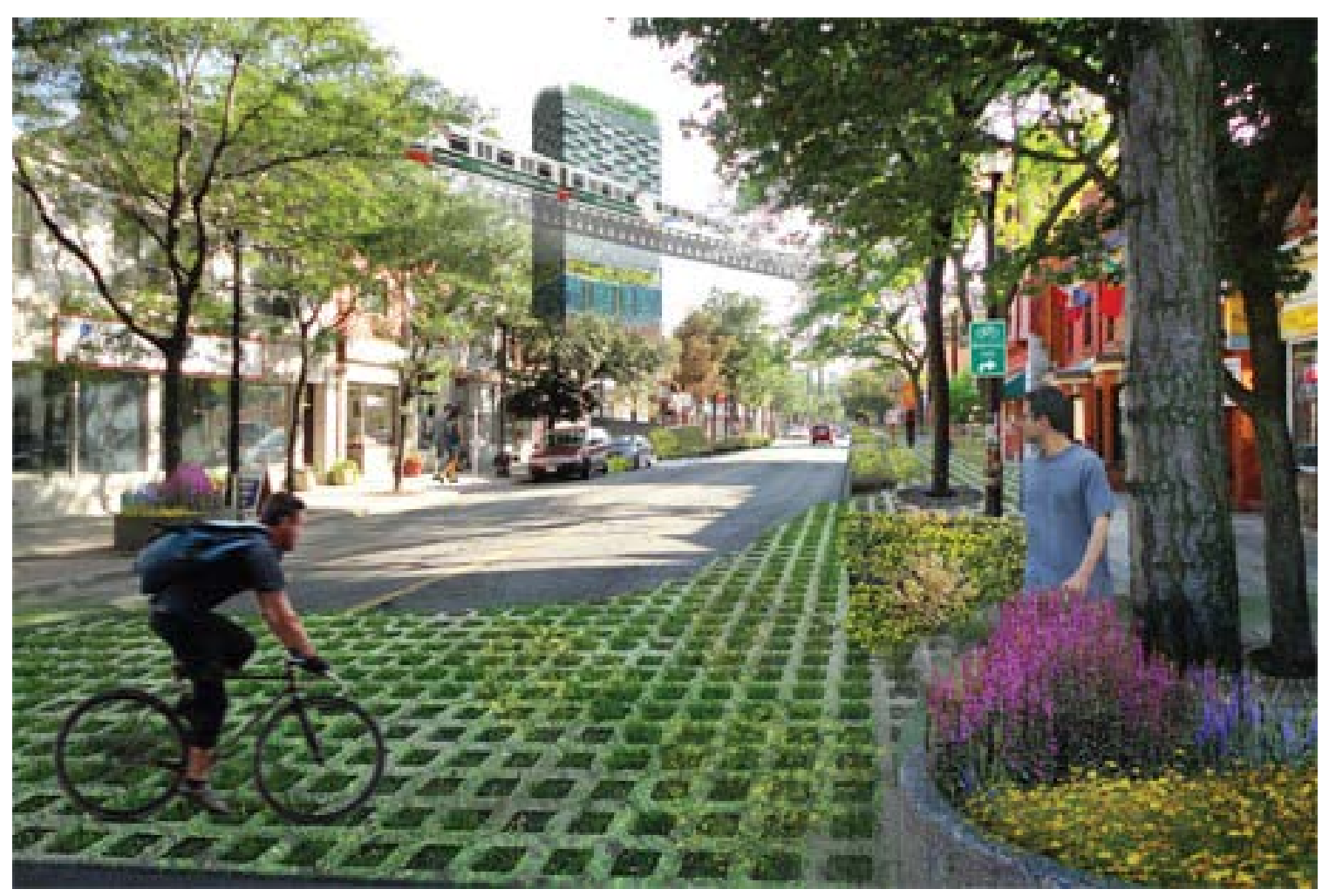

Ryc. 7. Miejska oaza. Źródło: http://www.ludazhao.com/images/pic03.jpg

\section{Podsumowanie}

Aby miasto można było uznać za sprzyjające seniorom istotne jest zdiagnozowanie problemów i sformułowanie oczekiwań starszych mieszkańców. Co jest istotne, projektant powinien szeroko konsultować swoje rozwiązania z samymi zainteresowanymi, gdyż to pomaga wypracować rozwiązania, z których z zadowoleniem korzystać będą mieszkańcy. Miasto zaprojektowane z uwzględnieniem potrzeb osób starszych bez wątpienia będzie odpowiadało również potrzebom pozostałych grup wiekowych, więc przyczyni się do ogólnego komfortu mieszkania, bezpieczeństwa i społecznego zadowolenia. Zapewnienie odpowiednich rozwiązań architektonicznych i inżynieryjnych we wspomnianych kluczowych kwestiach jest w stanie zapobiec zjawisku społecznej izolacji osób starszych i przyczyni się do zrównoważonego rozwoju obszarów miejskich.

\section{Bibliografia}

[1] Gehl, J., Gemzøe, L., New City Spaces, The Danish Architectural Press. 2000 Kopenhaga.

[2] Goldsmith S., Designing for the Disabled: the new paradigm, Architectural Press, 1997, Londyn.

[3] Lawton, M.P., Social ecology and the health of older people, American Journal of Public Health, Vol. 64., No. 3. 1994

[4] Ostańska A., Podstawy metodologii tworzenia programów rewitalizacji dużych osiedli mieszkaniowych wzniesionych w technologii uprzemystowionej na przykładzie osiedla im. ST. Moniuszki w Lublinie, Wydawnictwa Uczelniane, Lublin 2009

[5] Global age-friendly cities: a guide, World Health Organization, 2007 
Abstract: The aging of population is becoming a global trend observable in developed countries. According to the World Health Organization report1 (WHO), along with the development of cities in Europe and North America the percentage of people over 60 years old increases. This phenomenon is observable in Poland, mainly in the multi-family housing districts from the years 60ties up to 90ties of the twentieth century, where the large number of their original residents continue to live. The elderly, in most cases remain active physically, socially and are willing to participate in the development and improvement of living conditions in their place of residence. Architectural and urban solutions from the previous epoch, repeatedly pose a significant barriers to the full participation of older people in the local social life. These are solvable problems, however they require a substantial financial resources, in-depth analysis and skillful involvement of seniors in the of modernization. As, among others, a prominent Danish architect Jan Gehl2 advocates, a friendly city must adapt existing infrastructure and services provided in the housing estates to the needs of the elderly, with their active participation, as well as to offer new opportunities to counter their social exclusion. This is necessary in order to maintain the sustainable development of cities.

Keywords: aging, participation and social integration, architecture, urban planning, universal design. 